Postmodern Sublime 
This page intentionally left blank 


\section{POSTMODERN SUBLIME}

Technology and American Writing

from Mailer to Cyberpunk

Joseph Tabbi

CORNELL UNIVERSITY PRESS

ITHACA AND LONDON 
Copyright $\mathfrak{C} 1995$ by Cornell University

All rights reserved. Except for brief quotations in a review, this book, or parts thereof, must not be reproduced in any form without permission in writing from the publisher. For information, address Cornell University Press, Sage House, 512 East State Street, Ithaca, New York 14850.

First published 1995 by Cornell University Press.

First printing, Cornell Paperbacks, 1996.

Printed in the United States of America

(2) The paper in this book meets the minimum requirements of the American National Standard for Information Sciences-Permanence of Paper for Printed Library Materials, ANSI Z39.48-1984.

Library of Congress Cataloging-in-Publication Data

Tabbi, Joseph, 1960-

Postmodern sublime : technology and American writing from Mailer to Cyberpunk / Joseph Tabbi.

p. $\mathrm{cm}$.

Includes bibliographical references and index.

ISBN 0-8014-3074-7 (cloth)

ISBN o-8014-8383-2 (paper)

1. American literature-2oth century-History and criticism.

2. Literature and technology-United States-History-2oth century.

3. Postmodernism (Literature)-United States. 4. Sublime, The, in

literature. 5. Technology in literature. I. Title.

$\mathrm{PS}_{228 .} \mathrm{T}_{42} \mathrm{~T}_{33} 1995$

$810.9^{\prime} 384-$ dc2o 
To the memory of Terry Tabbi 
This page intentionally left blank 